\title{
Retropupillary iris-claw intraocular lens in ectopia lentis in Marfan syndrome
}

\section{Mun Yueh Faria' \\ Nuno Ferreira ${ }^{2}$ \\ Eliana Neto' \\ 'Vitreo Retinal Department, ${ }^{2}$ Ophthalmology Department, Santa Maria Hospital, Lisbon, Portugal}

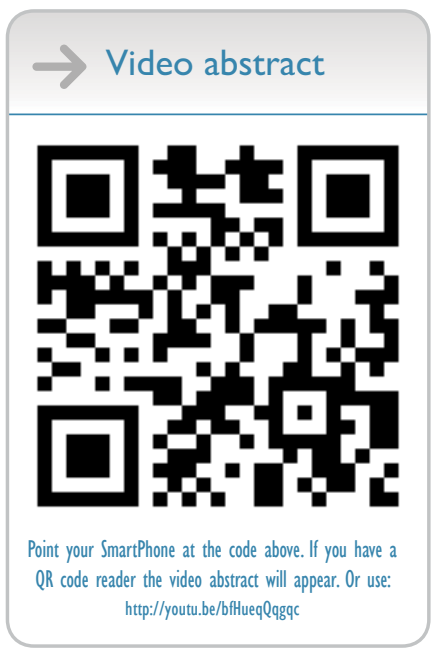

Correspondence: Mun Yueh Faria Vitreo Retinal Department, Santa Maria Hospital, Rua Prof Egas Moniz, 1649-035 Lisbon, Portugal

Emailmunfarial@gmail.com
This article was published in the following Dove Press journal:

International Medical Case Reports Journal

17 June 2016

Number of times this article has been viewed

Objective: To report visual outcomes, complication rate, and safety of retropupillary iris-claw intraocular lens (ICIOL) in ectopia lentis in Marfan syndrome (MFS).

Design: Retrospective study.

Methods: Six eyes of three MFS patients with ectopia lentis underwent surgery for subluxation lens and retropupillary ICIOL implantation from October 2014 to October 2015 at the Department of Ophthalmology, Santa Maria Hospital in Lisbon, Portugal. Demographics, preoperative and postoperative best-corrected visual acuity (BCVA), and intraocular pressure were evaluated. Endothelium cell count was assessed using specular microscopy; anterior chamber depth was measured using Pentacam postoperatively; and intraocular lens position was viewed by ultrasound biomicroscopy. All patients were female; mean age was $20 \pm 14.264$ years (range: 7-38 years).

Results: The average follow-up period was 6.66 months (range: 4-16 months). Preoperative BCVA was $0.568 \pm 0.149 \log$ MAR units, and postoperative BCVA was $0.066 \pm 0.121 \log$ MAR units. The mean BCVA gain was $-0.502 \pm 0.221$ on the logMAR scale. Postoperative average astigmatism and intraocular pressure were $1.292 \pm 0.697 \mathrm{mmHg}$ (range: $0.5-2.25 \mathrm{mmHg}$ ) and $16 \mathrm{mmHg}$ (range: $12-18 \mathrm{mmHg}$ ), respectively. The average endothelial cell density decreased from $3,121 \pm 178$ cells $/ \mathrm{mm}^{2}$ before surgery to $2,835 \pm 533$ cells $/ \mathrm{mm}^{2}$ after surgery (measured at last follow-up visit) and in the last follow-up, representing an average endothelial cell loss of $9.16 \%$. Mean anterior chamber depth was $4.01 \mathrm{~mm}( \pm 0.77 \mathrm{~mm})$, as measured by Pentacam. No complications were found intra- or postoperatively in any of the six studied eyes.

Conclusion: Retropupillary ICIOL implantation is a safe and effective procedure in the treatment of aphakia in MFS eyes, without capsular support after surgery for ectopia lens. The six eyes that underwent lensectomy and retropupillary ICIOL implantation have had excellent visual outcomes with no complications so far.

Keywords: retropupillary iris claw IOL, dislocated lens, aphakia

\section{Introduction}

Marfan syndrome (MFS) is a genetic disorder of connective tissue associated with mutation in fibrillin-1, an important component of the elastic microfibril of ciliary zonules. Weakness in the ciliary zonules causes them to stretch, resulting in ectopia lentis (40\%-56\%) and myopia (28\%), ectopia lentis being a major criterion for diagnosis of MFS. ${ }^{1}$ Mild displacement is sometimes asymptomatic, but frank subluxation, usually superotemporal, can cause diplopia or blurred vision.

Considering the age of patients with MFS, the expected life span, and eye growing modification, careful observations and surgical timing are required..$^{2}$ In significant 
subluxation with the equator of the lens in the pupillary axis, unstable vision is a clear indication for surgical approach.

Surgical procedures on zonular weakness and/or subluxated lens are challenging and depend on the surgeon's skill and experience. Surgery is indicated in these cases, but the best technique is still under debate. Intracapsular cataract extraction and anterior chamber intraocular lens (ACIOL) implantation, pars plana lensectomy, and scleral suture intraocular lens (IOL) have been described. ${ }^{3}$ Endocapsular flexible polymethyl methacrylate (PMMA) capsular tension ring or Cionni ring are used in small zonular displacement and in the bag, IOL is eventually placed. ${ }^{4-6}$

In cases of lens removal with no capsular support, irisclaw IOL (ICIOL) implantation has been used more commonly over the last decade. ${ }^{7,8}$

Although originally designed for fixation on the anterior surface of the iris, some case series showed advantage of fixating the ICIOL retropupillary, namely by maintaining the anterior chamber depth (ACD) and reducing the corneal endothelial cell loss. ${ }^{9}, 10$

In this protocol, six eyes of MFS patients were studied after surgery with lensectomy and retropupillary ICIOL implantation.

\section{Methods}

The study was performed in accordance with the tenets of the Declaration of Helsinki. The study was approved by the Ethics committee of Centro Academico de Medicina de Lisboa, Santa Maria Hospital. However, all patients signed consent for surgery, and informed consent was obtained from the patients included in this study or from their representative.

This retrospective study included six eyes of three MFS patients who underwent a Verisyse ${ }^{\circledast}$ (Abbott Laboratories Inc., Abbott Park, IL, USA) aphakic IOL implantation between October 2014 and October 2015 at the Ophthalmology Department of Santa Maria Hospital, Lisbon, Portugal.

Snellen visual acuity values were converted to the logarithm of the minimum angle of resolution (logMAR) for statistical analysis. Visual acuity of light perception was assigned as $2.9 \log \mathrm{MAR}$, hand movements as $2.6 \log \mathrm{MAR}$, and counting fingers as $2.3 \log$ MAR. Statistical analysis was performed using STATA v13.0 (StataCorp LP, College Station, TX, USA).

Preoperative data collected included demographics, intraocular pressure (IOP), and best-corrected visual acuity (BCVA). Operative data and postoperative outcomes included BCVA, lens position, IOP, and pigment dispersion. BCVA and IOP were measured on days 1 and 5 and postoperatively. BCVA and IOP were measured postoperatively at days 1 and

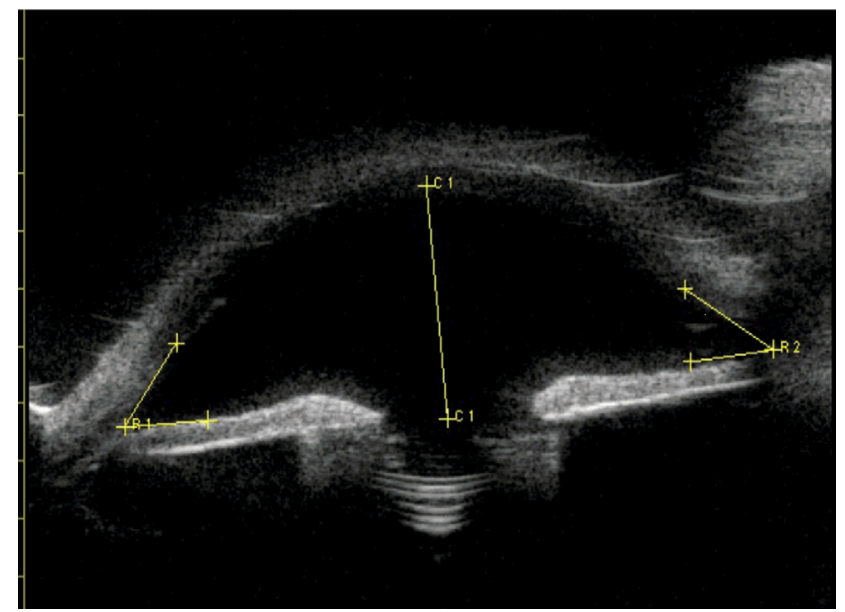

Figure I Ultrasound biomicroscopy showing intraocular lens position and open angle for the eye of patient number 3, with aphakia and retropupilar iris claw intraocular lens.

5, and after 1 and 3 months. Endothelial cell count (cells/ $\mathrm{mm}^{2}$ ), using a noncontact specular microscope, and the assessment of ACD and IOL positions, using Pentacam (Oculus, Wetzlar, Germany), were recorded at 3-month follow-up.

Ultrasound biomicroscopy was also performed in the 3-month follow-up to confirm IOL position, as in Figure 1, showing the right eye of patient number 3 .

\section{Surgical technique}

All surgeries were performed by the same surgeon (MYF) under general anesthesia, and the same surgical technique was used.

Lensectomy with 25 -gauge pars plana vitrectomy was performed and all prolapsed vitreous and remnants of cataract excised. Core pars plana vitrectomy was performed. After corneal endothelium viscoelastic protection, two small corneal paracentesis were created at the 3 or $9 \mathrm{o}$ 'clock position, and acetylcholine $1 \%$ was used whenever necessary for miosis, followed by injection of viscoelastic. A $5.4 \mathrm{~mm}$ corneal incision was made at the 12 o'clock position, and the ICIOL was then inserted in the concave-convex position, rotating the IOL to a horizontal plane and centered on the pupil. The optic of the reversed ICIOL was held with a forceps. One haptic was gently slid behind the iris; the optic was lifted slightly forward on the posterior surface of the iris so that the haptic could be recognized on the iris anterior surface. A long microspatula was used through the lateral paracentesis to insert iris tissue into the claw. The second haptic was fixated in the same way through the second paracentesis.

Only a small amount of iris tissue was enclavated at the claw haptics to avoid pupil ovalization. Corneal incision was 
closed with three simple interrupted 10-0 nylon sutures. No iridectomy was performed.

All viscoelastic was removed from the anterior chamber and exchanged with balanced saline solution. The retina periphery was assessed for breaks.

The IOL used in this study was the Verisyse ${ }^{\circledR}$ aphakia, which is a PMMA IOL of $8.5 \mathrm{~mm}$ length, $1.04 \mathrm{~mm}$ maximum height, and $5.4 \mathrm{~mm}$ optical zone width. The optic power was calculated using the SRK/T formula to achieve emmetropia. The manufacturer's recommendation for A constant is 116.5 for retropupillary implantation.

\section{Results}

All patients were female; mean age was $20.3 \pm 14.2$ years (range: $7-38$ years).

Four eyes in this study had inferonasal subluxation (Figure 2), and two eyes had superotemporal subluxation, outside visual axis, wearing aphakic correction for several years. The follow-up period was between 4 and 16 months, an average of 9 months. Preoperative and postoperative BCVA at last follow-up were 0.568 \pm 0.149 and $0.066 \pm 0.121 \log \mathrm{MAR}$ units, respectively. BCVA mean gain was $-0.502 \pm 0.22$ on the $\log$ MAR scale (Table 1). The average astigmatism after ICIOL implantation was 1.292 \pm 0.697 diopters (range:

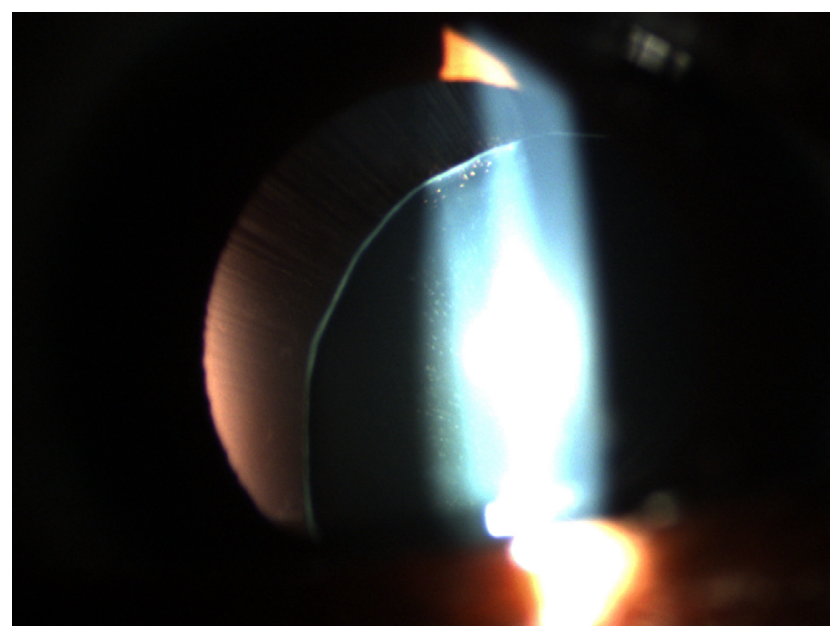

Figure 2 Inferonasal lens dislocation and stretched zonula of patient number 2.
0.5-2.25 diopters), and the average IOP was $14.5 \pm 2.074$ $\mathrm{mmHg}$ (range: $12-18 \mathrm{mmHg}$ ). The mean preoperative endothelial cell count was $3,121 \pm 178$ cells $/ \mathrm{mm}^{2}$, and the mean postoperative endothelium cell count was $2,835 \pm 533$ cells $/ \mathrm{mm}^{2}$, with a mean cell density loss of $9.16 \%$ (Table 2). The mean postoperative ACD measured by ultrasound biomicroscopy was 4.01 $\pm 0.77 \mathrm{~mm}$ (Figure 1).

\section{Discussion}

Ectopia lentis is a major criterion for diagnosis of MFS. Mild displacement is sometimes asymptomatic, but frank subluxation can cause diplopia or blurred vision. Considering the patient age, the expected life span, and eye modification of patients with MFS, careful observations and surgical timing are absolutely required. ${ }^{2}$ Significant subluxation with the equator of the lens in the pupillary axis and unstable vision may warrant surgical intervention. Surgery in zonular weakness or subluxated lens is a challenge and depends on surgeon's skill and experience. In these eyes, the best surgical technique is still under debate. In small zonular weakness with small displacement, capsular tension ring, flexible PMMA, or Cionni ring is used, and in the bag, IOL is placed. ${ }^{4-6}$ In significant subluxation, intracapsular cataract extraction or pars plana lensectomy and vitrectomy are used. The surgical management of aphakia without capsular support is often complex. To date, there is still no optimal surgical approach in these cases. ${ }^{11}$ Choices include ACIOLs, iris-sutured or scleral-sutured posterior chamber IOL, and ICIOL. ${ }^{12}$

Table 2 Patient ACD, ECC, and follow-up duration data

\begin{tabular}{lllll}
\hline $\begin{array}{l}\text { Patient } \\
\text { number }\end{array}$ & $\begin{array}{l}\text { ACD } \\
(\mathbf{m m})\end{array}$ & $\begin{array}{l}\text { ECC, preoperative } \\
\left(\mathbf{c e l l s} / \mathbf{m m}^{\mathbf{2}}\right)\end{array}$ & $\begin{array}{l}\text { ECC, last } \\
\text { follow-up visit } \\
\text { (cells/mm } \mathbf{m})\end{array}$ & $\begin{array}{l}\text { Follow-up, } \\
\text { (months) }\end{array}$ \\
\hline $\mathrm{I}$ & 4.2 & 3,338 & 3,238 & 16 \\
& 3.86 & 3,280 & 3,038 & 14 \\
2 & 2.97 & 3,188 & 3,088 & $1 \mathrm{I}$ \\
& 3.34 & 3,066 & 2,998 & 7 \\
3 & 4.75 & 2,974 & 2,874 & 9 \\
& 4.95 & 2,880 & 1,774 & 4 \\
\hline
\end{tabular}

Abbreviations: ACD, anterior chamber depth; ECC, endothelial cell count.

Table I Patient age, refraction, and VA data.

\begin{tabular}{|c|c|c|c|c|c|c|}
\hline $\begin{array}{l}\text { Patient } \\
\text { number }\end{array}$ & $\begin{array}{l}\text { Age at surgery } \\
\text { (years) }\end{array}$ & Eye & Refraction before & Refraction after & $\begin{array}{l}\text { Preoperative VA } \\
\text { (logMar) }\end{array}$ & $\begin{array}{l}\text { Postoperative } \\
\text { VA (logMar) }\end{array}$ \\
\hline \multirow[t]{2}{*}{ I } & 7 & $\mathrm{R}$ & -10.00 cil -4.00 & cil-0.5 & 0.397 & 0.096 \\
\hline & & $L$ & -5.00 cil -4.00 & -1.75 cil-I.25 & 0.522 & 0.301 \\
\hline \multirow[t]{2}{*}{2} & 16 & $\mathrm{R}$ & -6.00 cil-6.00 & -0.5 cil-I. 25 & 0.698 & 0 \\
\hline & & $L$ & -8.00 cil-7.00 & cil-I.00 & 0.397 & 0 \\
\hline \multirow[t]{2}{*}{3} & 38 & $\mathrm{R}$ & +9.50 & -1.50 cil-2.25 & 0.698 & 0 \\
\hline & & $\mathrm{L}$ & +9.50 & -0.5 cil-I.75 & 0.698 & 0 \\
\hline
\end{tabular}

Abbreviations: cil, cylinder; L, left; R, right; VA, visual acuity. 
In 1972, Worst et al presented the first ICIOL, a biconvex PMMA IOL, fixated at anterior surface of iris, at mid-periphery. ${ }^{13}$ The Verisyse ${ }^{\circledR}$ aphakic IOL, one of the latest versions of the iris-fixated ACIOL, with a convex-concave design, is associated with fewer complications. ${ }^{14}$ The surgical time is reduced, the technique has a short learning curve, and it is associated with a good visual outcome and a low incidence of intraoperative and postoperative complications. The classic recommendation is to position the ICIOL above the iris in cases of aphakia. ${ }^{12}$

Hirashima et $\mathrm{al}^{7}$ studied 31 eyes of 16 patients with subluxated lenses associated with MFS - one group with phacoemulsification and iris-fixated PCIOL implantation and the other group with phacoemulsification and iris-claw ACIOL implantation. Although IOL dislocation tended to occur more frequently in the iris-fixated PCIOL group, the difference was

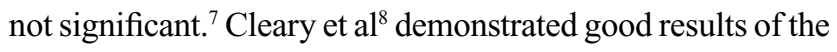
use of Verisyse ${ }^{\circledR} /$ Artisan $^{\circledR}$ iris-claw lens implants in eight eyes of five children with aphakia following lensectomy for ectopia lentis. Mean endothelial cell count was 3,312 \pm 277 cells $/ \mathrm{mm}^{2}$ preoperatively and $2,913 \pm 268$ cells $/ \mathrm{mm}^{2}$ postoperatively, representing a mean cell loss of $14.2 \%(P<0.001)$. Gonnermann et $\mathrm{a}^{15}$ had the largest case series of MFS and retropupillar ICIOL, with 13 eyes of ten MFS patients. They found a low complication rate with a mean endothelial cell loss of $5.6 \%$.

ICIOL implantation has been used more commonly over the last decade. Although originally designed for fixation on the anterior surface of the iris, some case series showed some advantage on fixating the ICIOL retropupillary, namely, by maintaining the ACD and reducing the corneal endothelial cell loss. ${ }^{16}$ With the advent and safety of 25- and 23-gauge pars plana vitrectomy, lensectomy and ICIOL in a retropupillary position seem to be an easy and low time-consuming technique.

To our best knowledge, this is the first presentation of MFS patients treated with lensectomy, pars plana vitrectomy, and retropupillar ICIOL. Our outcomes of visual acuity, astigmatism, and endothelium cell count are comparable to, and in some cases better than, other alternative techniques and IOLs.

Short cohort series and short follow-up time are the limitations of our study. So far, the results are good and seem promising.

\section{Conclusion}

Lensectomy, pars plana 25-gauge vitrectomy, and retropupillary iris-claw implantation appear to be safe and effective procedures when treating MFS patients with ectopia lentis. The endothelial cell loss of $9.16 \%$ seems to be acceptable, and we have found no complications so far.

\section{Disclosure}

The authors report no conflicts of interest in this work.

\section{References}

1. Dean JC. Marfan syndrome: clinical diagnosis and management. Eur J Hum Genet. 2007;15(7):724-733.

2. Matsuo T. How far is observation allowed in patients with ectopia lentis? Springerplus. 2015;4:461.

3. Shah R, Weikert MP, Grannis C, Hamill MB, Kong L, Yen KG. Longterm outcomes of iris-sutured posterior chamber intraocular lenses in children. Am J Ophthalmol. 2016;161:44-49.e1.

4. Rai G, Sahai A, Kumar PR. Outcome of capsular tension ring (CTR) implant in complicated cataracts. J Clin Diagn Res. Epub 2015 Dec 1.

5. Marques DMV, Marques FF, Cionni RJ, Osher RH, Freitas LL. Avaliação do uso do anel endocapsular modificado em casos de subluxação traumática do cristalino. [Evaluation of the modified capsular tension ring in cases of traumatic lens subluxation]. Arq Bras Oftalmol. 2007;70(5):746-51. Portugese.

6. Vasavada V, Vasavada VA, Hoffman RO, Spencer TS, Kumar RV, Crandall AS. Intraoperative performance and postoperative outcomes of endocapsular ring implantation in pediatric eyes. $J$ Cataract Refract Surg. 2008;34(9):1499-1508.

7. Hirashima DE, Soriano ES, Meirelles RL, Alberti GN, Nosé W. Outcomes of iris-claw anterior chamber versus iris-fixated foldable intraocular lens in subluxated lens secondary to Marfan syndrome. Ophthalmology. 2010;117(8):1479-1485.

8. Cleary C, Lanigan B, O'Keeffe M. Artisan iris-claw lenses for the correction of aphakia in children following lensectomy for ectopia lentis. Br J Ophthalmol. 2012;96(3):419-421.

9. Gonnermann J, Amiri S, Klamann M, et al. Endothelzellverlust nach retropupillar fixierter Irisklauen-Linse [Endothelial cell loss after retropupillary iris-claw intraocular lens implantation]. Klin Monbl Augenheilkd. 2014;231(8):784-787. German.

10. Gonnermann J, Torun N, Klamann MK, Maier AK, von Sonnleithner C, Bertelmann E. Posterior iris-claw aphakic intraocular lens implantation in subluxated lenses due to Marfan syndrome. Eur J Ophthalmol. 2014;24(3):352-357.

11. Dick HB, Augustin AJ. Lens implant selection with absence of capsular support. Curr Opin Ophthalmol. 2001;12(1):47-57.

12. Acar N, Kapran Z, Altan T, Kucuksumer Y, Unver YB, Polat E. Secondary iris claw intraocular lens implantation for the correction of aphakia after pars plana vitrectomy. Retina. 2010;30(1):131-139.

13. Worst JG, Massaro RG, Ludwig HH. The introduction of an artifitial lens into the eye using Binkhorst's technique. Ophthalmologica. 1972;164(5):387-391.

14. Schallenberg M, Dekowski D, Hahn A, Laube T, Steuhl K-P, Meller D. Aphakia correction with retropupillary fixated iris-claw lens (Artisan)long-term results. Clin Ophthalmol. 2014;8:137-41.

15. Gonnermann J, Torun N, Klamann MK, et al. Posterior iris-claw aphakic intraocular lens implantation in children. Am J Ophthalmol. 2013;156(2):382-386.e1.

16. Wolter-Roessler M, Küchle M. Ergebnisse der Aphakiekorrektur durch retroiridal fixierte Kunstlinse [Correction of aphakia with retroiridally fixated IOL]. Klin Monbl Augenheilkd. 2008;225(12):1041-1044. German. 
International Medical Case Reports Journal

The International Medical Case Reports Journal is an international, peer-reviewed open-access journal publishing original case reports from all medical specialties. Previously unpublished medical posters are also accepted relating to any area of clinical or preclinical science. Submissions should not normally exceed 2,000 words or
4 published pages including figures, diagrams and references. The manuscript management system is completely online and includes a very quick and fair peer-review system, which is all easy to use. Visit $\mathrm{http}: / /$ www.dovepress.com/testimonials.php to read real quotes from published authors.

Submit your manuscript here: https://www.dovepress.com/international-medical-case-reports-journal-journal 